\title{
Effect of Playing Venue on Hormonal Responses, Psychological State, and Perception of Effort in Inter-University Basketball Players
}

Yasmeen Tabassum

University of the Punjab

Muhammad Zafar lqbal Butt

University of the Punjab

Nabila Roohi

University of the Punjab

Muhammad Abdul Jabar Adnan

University of the Punjab

Sitaram Khadka ( $\nabla$ sitaram.khadka@naihs.edu.np)

Shree Birendra Hospital, Nepalese Army Institute of Health Sciences

Muhammad Amir lqbal

University of the Punjab

Ravi Prasad Gupta

Punjab University College of Pharmacy, University of the Punjab

Pallav Aryal

Punjab University College of Pharmacy, University of the Punjab

\section{Research Article}

Keywords: Basketball, Hydrocortisone, Testosterone, Anxiety, Perception

Posted Date: April 20th, 2021

DOl: https://doi.org/10.21203/rs.3.rs-426616/v1

License: (c) (i) This work is licensed under a Creative Commons Attribution 4.0 International License.

Read Full License 


\section{Abstract}

Background: Playing venue conditions is a prominent contributor to the performance of players in a competition. Hence, the present study was designed to evaluate the effect of playing venue on the hormonal responses, psychological state, and perception of effort in inter-university basketball players.

Methods: A total of 96 male basketball players from eight different public and private sector universities were monitored during eight competitive matches played against each other on a home and away ground. Testosterone and cortisol levels were measured before and after each match. The psychological state test was conducted before each match and the perception of effort score was taken after the match.

Results: Elevated testosterone levels, before playing a match, as evidenced at home ground, however, a $4 \%$ decline was recorded in testosterone level at away venue, even before playing the match. Both testosterone and cortisol levels depicted the same trend on home as well as away ground. Pre-match testosterone concentration and the percent changes in these hormones were related to self-confidence, especially when playing at home, and cortisol pre and post concentration related to cognitive anxiety, somatic anxiety, and perception of effort.

Conclusions: The playing influenced hormonal responses before the commencement of basketball matches at away ground. These hormonal responses were related to players' psychological state, which might contribute to players' behavior and outcomes of matches.

\section{Background}

Basketball is a sport played by two teams on a rectangular court, each with five players [1]. There are many strategies for ball-handling, shooting, passing, dribbling, and rebounding in this game. Basketball is an irregular sport characterized by high-intensity activity and low-intensity recovery periods [2]. Highintensity activity periods comprise high-speed running, jumping, sprinting, and bodily contact, while, lowintensity recovery periods contain standing, walking, and jogging movements [3]. These activities are performed over four quarters in a basketball match [4]. Probably, the high-intensity demands during the match may cause stress to the immune, endocrine, and muscular systems [5]. In this context, a playing venue is a valid tool for monitoring a player's hormonal response and anxiety levels because a home playing venue provides a comfort zone to a player [6 - 8].

Testosterone $(\mathrm{T})$, a steroid hormone, is linked up with the assertive behavior of the players, which contributes to increased performance at home as well as away grounds [9]. This hormone also has a crucial role in maintaining territoriality in the kingdom Animalia [10]. Cortisol, a stress hormone, produced by the adrenal cortex, also responds to the competitive environment [11]. Anxiety level increases when the athletes perform at an away playing venue [6]. It results in situations that cause failure, misfortune, and danger to the individuals [12]. The anxiety occurs in individuals before the competition due to the 
concerns related to the competition as well as when athletes feel an important and strong threat against themselves such as an injury, shame, or loss of prestige $[12,13]$.

Competitive state anxiety has three sub-scales; cognitive anxiety, somatic anxiety, and self-confidence. Cognitive anxiety may be caused by negative images and thoughts created by the persons about themselves [14]. On the other hand, somatic anxiety expresses itself with a person's physical symptoms and concerns the physiological and behavioral dimensions of anxiety [15]. Physiological and behavioral dimensions directly influence the person as a result of the excitement and show sudden development [15]. Self-confidence during sports activities is a well-documented phenomenon that increases along with the understanding of the player about the game [16]

Perception of the effort; which is based on the conscious sensations comprising toughness, heaviness, and strenuousness of a physical task; is measured by the rating of perceived exertion (RPE) of the players after a competition [17].

This study is conducted with the objectives to check the effect of playing venues on hormonal responses of basketball players that how testosterone and cortisol concentrations vary, assess the players' overall anxiety scores with its three different subscales, and lastly, determine the perception of effort on both home and away venues.

\section{Methods}

\section{Ethics approval}

The ethics approval was granted by the Institutional Review Board (IRB)/Ethics Committee, University of the Punjab, Lahore, Pakistan. The research has been performed in accordance with the Declaration of Helsinki. Informed consent to participate in the study was obtained prior to conduct the study from participants as well as their directors and team management committee.

\section{Study design and participants}

This is a cross-sectional descriptive as well as an experimental study conducted among 96 basketball players from eight public and private universities in Lahore, Pakistan. All the players were physically fit, had participated in the Higher Education Commission (HEC) inter-university sports competition 2016-17, and with an age ranging from 18 to 24 years. Players were involved in their routine training schedule.

\section{Study procedure}

To collect the data of both the home venue and away venue competition, basketball matches were organized in such a way that every team got a chance to play one match in-home venue and one match on an away venue with the same opponent team. 
Blood sampling was done before sixty minutes of the commencement of the match. A registered medical technician from a patent pathology laboratory, under the supervision of a qualified medical practitioner, was hired for the blood sampling of recruiting players for pre-test analysis, keeping in view all the ethical aspects. Then, players were allowed to play the match. After 15 minutes, again blood sampling was done for the post-test analysis. The same practice was repeated in all eight basketball matches with the timelapse of one match after every three days early in the morning after getting an eight-hour normal sleep on average and a standard local breakfast with basic macro and micronutrients. Every time after taking the blood sample medical staff shifted the samples to the laboratory for assessment of testosterone and cortisol levels in the blood before and after the matches. Testosterone and cortisol assessment was done by the enzyme-linked immunosorbent assay (ELISA) method.

The psychometric assessment was done 30 minutes before the match using competitive state anxiety inventory-2 (CSAI-2) [18]. Both teams were preceded by warm-up, light coordination exercises, show ball drills, and stretching of the major muscle groups. Each player was asked to perform in normal psychological mode with no extra pressure. The Illinois Competition Test or CSAl-2 consists of 27 items, with 9 items for each subscale, named cognitive anxiety, somatic anxiety, and self-confidence [18]. All items were rated on a 4-point Likert scale.

Perception of effort was measured after the match, through the session-RPE score [19] to quantify the internal training load. In the present study, this scale was used to assess the player's match intensity after the match, wherein, each player rated the match intensity using the CR-10 sliding scale, with $1=$ nothing at all and $10=$ very hard. Match intensity was assessed after 30 minutes of the match ending [20]. A simple question was asked to the players, "How was your workout" and their responses were taken to a chart outlining the full RPE scale with the appropriate explanations. This method is considered a valid, useful, and practical method for monitoring the competitive intensity of the players.

\section{Statistical analysis}

Results were analyzed, statistically by pairing sample " $\mathrm{t}$ " test [21], to work out the significance variations amongst the parameters of the study, in comparable groups. Secondly, descriptive statistics were applied to measure psychometric assessment on psychological state and perception of the effort of the players.

\section{Results}

Significant reduction $(P<0.001)$ of $11 \%$ in post-test testosterone levels was evidenced at the home ground when compared with pre-test levels. Prominent reduction $(P<0.001)$ of $16 \%$ in the post-test testosterone level was noticed at an away ground as compared to pre-test testosterone levels. A mild difference was present in testosterone level in pre-test $v s$ pre-test comparison of basketball players while, playing on a home and away playing venues, respectively. Obvious reduction $(P<0.001)$ of $19 \%$ was present in post-test testosterone level at an away ground, as compared to pre-test levels of the home ground venue. Non-significant variation was present in post-test $v s$ pre-test comparison of testosterone level of basketball players, while, playing on a home and away playing venues, respectively. Marked 
$(P<0.05)$ reduction of $9 \%$ was evidenced in post-test testosterone level on away ground, as compared to the post-test analysis of testosterone at home ground (Fig. 1, Table 1).

Significant elevation $(P<0.001)$ of $34 \%$ was evidenced in post-test cortisol levels of basketball players as compared to pre-test levels, while, playing on their home ground. Pre-test and post-test comparison of cortisol level of basketball players depicted marked elevation $(P<0.001)$ of $16 \%$ in the post-test analysis as compared to pretest levels on away ground. Considerable elevation $(P<0.01)$ of $16 \%$ was presented in pre-test cortisol levels at away ground as compared to the pre-test cortisol level at home ground. Prominent elevation $(P<0.001)$ of $25 \%$ was presented in post-test cortisol level at away ground as compared to pre-test cortisol level at home ground. Significant decline $(P<0.05)$ of $13 \%$ was evidenced in pre-test cortisol level at away ground as compared to post-test cortisol level at home ground. Nonsignificant variations were observed in post-test $v s$ post-test comparison of cortisol level of basketball players while playing at home and away playing venues, respectively (Table 2; Fig. 2).

The psychological state of basketball players on home and away grounds regarding cognitive state anxiety shows that players feel more cognitive anxiety on away grounds as compared to their home grounds. The average cognitive state anxiety score on the away ground was mildly increased by $14 \%$, as compared to the home ground (Fig. 3). Whereas, prominent elevation $(P<0.001)$ was presented by somatic state anxiety score at away ground as compared to the home ground (Fig. 3). Players feel more confident on their home grounds as compared to away ground. The average self-confidence score on the away ground was declined non-significantly as compared to the home ground. (Fig. 3; Table 3).

There is a remarkable elevation $(P<0.001)$ of $34 \%$ in basketball players' physical exertion score on away venues as compared to home ground.

\section{Discussion}

There are several key findings of this study, conducted on male inter-university basketball players. It was observed that when players performed at their home playing venue, their level of testosterone was raised and they also won the matches due to an increased score self-confidence. Further, it was also documented in the current study that the cortisol level of players was elevated due to an increased score

of physical exertion (perception of effort) cognitive and somatic anxiety, on away ground before and after the match.

The current research found that playing venue affects the player's pre-match hormonal responses on the home ground as well as on away ground even he did not play his match.

Testosterone, particularly, among males, is an anabolic hormone that influences sports competition by increasing motivation and physical ability to compete [22]. In our findings, the testosterone level was significantly elevated on the home ground and decreased on the away ground. The trend of reduced 
testosterone levels in players was seen on away playing ground situations in comparison to the testosterone level of the same players on their home ground, it was declined just because of the changing the playing venue. Moreover, this reduced trend of testosterone might harm away from playing venues. The reduced testosterone level might halt the overall performance of game tactics and poor skill execution resulting in losing a match on grounds other than home.

Some studies found no alteration in the hormonal profile of playing at the home venue or away venue [23, 24]. Whereas, some researchers found a significant difference in the hormonal profile of players who are participating in the competition, played at home venue as compared to those players who are playing away from the home ground.

Additionally, it has been documented earlier that the concentration of testosterone hormone increases after winning the competition, either it is in the home ground or away from the home ground [8].

Cortisol is a catabolic hormone, belonging to the steroid category, has an association with uncontrolled and unstable conditions [24]. It is also called the stress hormone. When any emergency and competitive situations are encountered, it prepares the human body to respond to the stressor stimulus. The challenging conditions and appraisal of threatening are associated with increased cortisol levels that might be due to the hypothalamic-pituitary-adrenal axis (HPA) responses to both psychological and physical stress from the external environment [25].

Whenever, any sign of disturbance is observed, HPA response through cortisol biosynthesis acts as an indicator of stress condition [26]. In response to the unstable and stressful conditions, cortisol begins to rise. For example, in a competitive state, a player encounters several psychological stimulators and stressors, perpetuating the rising of cortisol that results in altered glucose level, cardiovascular activation, and anti-inflammatory responses to tackle the overwhelming stress [27].

In our study, the level of cortisol was significantly elevated on away ground due to an increased level of cognitive anxiety, somatic anxiety, physical exertion, less support of the crowd, referee's biased decision against visiting team, and traveling fatigue. In the current study, it was observed that level of cortisol was also decreased on the home ground due to the balanced and supportive environment of the playing venue.

It was also observed that athletes who were performing away from their home grounds had felt a high level of cognitive and somatic anxiety [6]. In another investigation of tennis players, somatic anxiety was positively correlated with the concentration of Cortisol [20]. Whereas, in another research, a positive relation was observed between pre and post-fight cortisol levels in Judaists and somatic anxiety. Somatic anxiety, testosterone, and pre-round cortisol in the competition of golf also expressed the same similar trends [28].

Generally, in sports competitions, variations in behavior and physical expressions are caused by the hormonal changes mediated by the triggering of HPA in response to the externally stimulating factors. 
It has been investigated by researchers, the negative relationship between cognitive anxiety and salivary testosterone level was documented on playing venues away from his home venue depicting that when a player is performing, he feels worried, apprehension and nervousness, due to an unfamiliar attitude with the playing venue [29]. Hence, location also influences psychological factors such as the level of state anxiety.

It has been found in another study the score of trait and state anxiety in the final match of the tournament as compared to the semifinal match [30]. About the location of the tournament, these researches indicated that the athletes who were playing in the opponent's venue had a higher level of somatic and cognitive anxiety as compared to players who were playing on home grounds.

In our findings, we investigated that basketball players felt more somatic and cognitive anxiety, while, playing on away ground before the commencement of the match. Whereas, their self-confidence score was evaluated higher on their home ground before the start of the match.

In our findings, on both home and away from the ground, the players' physical exertion score was evaluated higher after the match, due to increased levels of cognitive anxiety, somatic anxiety, and elevated cortisol level.

The RPE is one's sensation about the intense, hard, and vigorous workout. As the pacing strategy changes with the competition, the rate of RPE also changes. During the competition, the score of RPE progression has a linear relationship between the certainty of endpoint and the duration of the competition [31].

In official basketball matches, high RPE was found when a comparison was made between professional players in simulated competitions [32]. In those competitions, greater RPE was noticed among players because matches were played at higher intensities due to increased physical and psychological demands.

\section{Conclusion}

Conclusively, the outcomes of the present investigation suggest that changing the playing venue influences the hormonal responses of the players. Testosterone, in basketball players, demonstrated a reducing trend, on venue other than the home ground, even before playing the match, proposing unfamiliar conditions negatively influences the performance of players.

Moreover, cortisol depicted an increasing trend as the players move from home to away ground. This can be due to unfamiliar conditions of away ground venues influencing HPA resulting in elevated cortisol levels. Somatic state anxiety and perception of effort also demonstrated an increasing trend on away grounds deducing that players on away grounds perform less to low skill execution and reduced selfconfidence.

\section{Abbreviations}


AG Post B: Away ground post-test basketball

AG Pre B: Away ground pre-test basketball

CSAI-2: Competitive state anxiety inventory-2

ELISA: Enzyme-linked immunosorbent assay

HEC: Higher Education Commission

HG Post B: Home ground post-test basketball

HG Pre B: Home ground pre-test basketball

HPA: Hypothalamic-pituitary-adrenal axis

IRB: Institutional Review Board

RPE: Rating of perceived exertion

\section{Declarations}

\section{Ethics approval and consent to participate}

The ethics approval was granted by the Institutional Review Board (IRB)/Ethics Committee, University of the Punjab, Lahore, Pakistan. The research has been performed in accordance with the Declaration of Helsinki. Informed consent to participate in the study was obtained prior to conduct the study from participants as well as their directors and team management committee.

Consent for publication

Not applicable

Availability of data and materials

The datasets used and/or analyzed during the current study available from the corresponding author on reasonable request.

Competing interests

The authors declare no competing conflict of interest.

\section{Funding}

No funding was obtained from any source.

\section{Authors' contributions}


Yasmeen Tabassum: Conceptualization, Methodology, Formal analysis, Investigation, Data curation, and Writing - original draft preparation. Muhammad Zafar Iqbal Butt: Resources, Validation, and Project administration. Nabila Roohi: Supervision, Investigation, and Writing- reviewing and editing Muhammad Abdul Jabar Adnan: Methodology, Formal analysis, Writing- reviewing and editing. Sitaram Khadka: Conceptualization, Visualization, Writing- reviewing and editing. Muhammad Amir lqbal: Formal analysis, Investigation. Ravi Prasad Gupta: Data curation, Investigation. Pallav Aryal: Data curation, Investigation.

\section{Acknowledgements}

We are highly thankful to the university basketball players in Lahore, Pakistan who were recruited for this research.

\section{Authors' information}

Yasmeen Tabassum, PhD

Department of Sport Sciences and Physical Education, University of the Punjab, Lahore, Pakistan yasmeentabassum111@gmail.com

Muhammad Zafar Iqbal Butt

Department of Sport Sciences and Physical Education, University of the Punjab, Lahore, Pakistan zafarbutt666@hotmail.com

Nabila Roohi

Physiology/Endocrinology Laboratory, Department of Zoology, University of the Punjab, Lahore, Pakistan nabilaruhi@gmail.com

Muhammad Abdul Jabar Adnan

Department of Sport Sciences and Physical Education, University of the Punjab, Lahore, Pakistan abduljabar_4@yahoo.com

Sitaram Khadka, PharmD

Shree Birendra Hospital; Nepalese Army Institute of Health Sciences, Kathmandu, Nepal

Punjab University College of Pharmacy, University of the Punjab, Lahore, Pakistan sitaram.khadka@naihs.edu.np

Muhammad Amir Iqbal 
Physiology/Endocrinology Laboratory, Department of Zoology, University of the Punjab, Lahore, Pakistan

amir87zoologist@gmail.com

Ravi Prasad Gupta

Punjab University College of Pharmacy, University of the Punjab, Lahore, Pakistan

ravigup5566@gmail.com

Pallav Aryal

Punjab University College of Pharmacy, University of the Punjab, Lahore, Pakistan

paryal2014@gmail.com

\section{References}

1. Pratheep Kumar V, Kalaiselvi M. Effects of Varied Surface of Circuit Plyometirc Training on Speed and Speed Endurance Performance of School Level Basketball Players. Indian J Public Heal Res Dev. 2020;11(7).

2. Castagna C, Krustrup P, Póvoas S. Cardiovascular fitness and health effects of various types of team sports for adult and elderly inactive individuals - a brief narrative review. Prog Cardiovasc Dis. 2020;63(6):709-22. https://doi.org/10.1016/j.pcad.2020.11.005

3. van Gogh MJ, Wallace LK, Coutts AJ. Positional Demands and Physical Activity Profiles of Netball. J strength Cond Res. 2020 May;34(5):1422-30. https://doi.org/10.1519/JSC.0000000000002388

4. Reina M, García-Rubio J, Esteves PT, Ibáñez SJ. How external load of youth basketball players varies according to playing position, game period and playing time. Int J Perform Anal Sport [Internet]. 2020;20(6):917-30. https://doi.org/10.1080/24748668.2020.1818973

5. Kirwan R, McCullough D, Butler T, Perez de Heredia F, Davies IG, Stewart C. Sarcopenia during COVID19 lockdown restrictions: long-term health effects of short-term muscle loss. GeroScience. 2020 Dec;42(6):1547-78. https://doi.org/10.1007/s11357-020-00272-3

6. Carolina-Paludo A, Nunes-Rabelo F, Maciel-Batista M, Rúbila-Maciel I, Peikriszwili-Tartaruga M, Simões A. Game location effect on pre-competition cortisol concentration and anxiety state: A case study in a futsal team. Rev Psicol Deport. 2020;29:105-12.

7. Ponzo M, Scoppa V. Does the Home Advantage Depend on Crowd Support? Evidence From SameStadium Derbies. J Sports Econom [Internet]. 2018;19(4):562-82. Available from:

https://econpapers.repec.org/RePEc:sae:jospec:v:19:y:2018:i:4:p:562-582 https://doi.org/10.1177/1527002516665794

8. Fothergill M, Wolfson S, Neave N. Testosterone and cortisol responses in male soccer players: The effect of home and away venues. Physiol Behav. 2017 Aug;177:215-20. 
https://doi.org/10.1016/j.physbeh.2017.04.021

9. Massimino S, Rinella S, Buscemi A, Similia E, Perciavalle V, Perciavalle V, et al. Digit ratio, personality and emotions in skydivers. Biomed reports. 2019 Jan;10(1):39-46.

https://doi.org/10.3892/br.2018.1174

10. Apfelbeck B, Flinks H, Goymann W. Territorial aggression does not feed back on testosterone in a multiple-brooded songbird species with breeding and non-breeding season territoriality, the European stonechat. Horm Behav [Internet]. 2017;87:89-95. Available from:

https://www.sciencedirect.com/science/article/pii/S0018506X16302008 https://doi.org/10.1016/j.yhbeh.2016.11.002

11. Jiménez M, Alvero-Cruz JR, Solla J, García-Bastida J, García-Coll V, Rivilla I, et al. Competition Seriousness and Competition Level Modulate Testosterone and Cortisol Responses in Soccer Players. Int J Environ Res Public Health. 2020 Jan;17(1). https://doi.org/10.3390/ijerph17010350

12. Agaoglu Y. Responses to the Competitive State Anxiety Inventory-2 by the Athletes Participated in the (IJF) Judo Grand Prix Competition, Samsun 2015 in Turkey. Int J Environ Sci Educ. 2016;11(10):3259-75.

13. Chadha NJ, Turner MJ, Slater MJ. Investigating Irrational Beliefs, Cognitive Appraisals, Challenge and Threat, and Affective States in Golfers Approaching Competitive Situations. Front Psychol. 2019;10:2295. https://doi.org/10.3389/fpsyg.2019.02295

14. Orska R. Support for Measures for Adolescents' School Anxiety Mitigation. Soc Welf Interdiscip Approach. 2018;2(7):31-45. https://doi.org/10.21277/sw.v2i7.317

15. Nesterko Y, Jäckle D, Friedrich M, Holzapfel L, Glaesmer H. Factors predicting symptoms of somatization, depression, anxiety, post-traumatic stress disorder, self-rated mental and physical health among recently arrived refugees in Germany. Confl Health. 2020;14:44. https://doi.org/10.1186/s13031-020-00291-z

16. Heeren A, Bernstein EE, McNally RJ. Deconstructing trait anxiety: a network perspective. Anxiety Stress Coping. 2018 May;31(3):262-76. https://doi.org/10.1080/10615806.2018.1439263

17. Kanniyan A. Competitive State Anxiety: Impact of Positive Self Talk Training on Junior Level Football Players. In 2015.

18. Batista M, Catarino J, Fernandes H, Vaz L, Serrano J, S H. Anxiety levels in" Under 18" and" Under 20" Elite Rugby Players of National Teams in different field positions. Retos nuevas tendencias en Educ física, Deport y recreación. 2019;35:369-73. https://doi.org/10.47197/retos.v0i35.63734

19. Gomes R, Moreira A, Lodo L, Capitani C, Aoki M. Ecological validity of session RPE method for quantifying internal training load in tennis. Int J Sports Sci Coach. 2015;10(4):729-37. https://doi.org/10.1260/1747-9541.10.4.729

20. Arruda AFS, Aoki MS, Freitas CG, Drago G, Oliveira R, Crewther BT, et al. Influence of competition playing venue on the hormonal responses, state anxiety and perception of effort in elite basketball athletes. Physiol Behav [Internet]. 2014;130:1-5. Available from: 
https://www.sciencedirect.com/science/article/pii/S0031938414001413 https://doi.org/10.1016/j.physbeh.2014.03.007

21. Carré J, Muir C, Belanger J, Putnam SK. Pre-competition hormonal and psychological levels of elite hockey players: relationship to the "home advantage". Physiol Behav. 2006 Oct;89(3):392-8. https://doi.org/10.1016/j.physbeh.2006.07.011

22. Handelsman DJ, Hirschberg AL, Bermon S. Circulating Testosterone as the Hormonal Basis of Sex Differences in Athletic Performance. Endocr Rev. 2018 Oct;39(5):803-29. https://doi.org/10.1210/er.2018-00020

23. Gray PB, McHale TS, Carré JM. A review of human male field studies of hormones and behavioral reproductive effort. Horm Behav. 2017 May;91:52-67. https://doi.org/10.1016/j.yhbeh.2016.07.004

24. Casto K, Edwards D. Before, during, and after: how phases of competition differentially affect testosterone, cortisol, and estradiol levels in women athletes. Adapt Hum Behav Physiol. 2016;2(1):11-25. https://doi.org/10.1007/s40750-015-0028-2

25. Popma A, Vermeiren R, Geluk CAML, Rinne T, van den Brink W, Knol DL, et al. Cortisol Moderates the Relationship between Testosterone and Aggression in Delinquent Male Adolescents. Biol Psychiatry [Internet]. 2007;61(3):405-11. Available from: https://www.sciencedirect.com/science/article/pii/S0006322306007980 https://doi.org/10.1016/j.biopsych.2006.06.006

26. van Dalfsen JH, Markus CR. The influence of sleep on human hypothalamic-pituitary-adrenal (HPA) axis reactivity: A systematic review. Sleep Med Rev [Internet]. 2018;39:187-94. Available from: https://www.sciencedirect.com/science/article/pii/S1087079217301119 https://doi.org/10.1016/j.smrv.2017.10.002

27. Wright RJ, Newby DE, Stirling D, Ludlam CA, Macdonald IA, Frier BM. Effects of acute insulin-induced hypoglycemia on indices of inflammation: putative mechanism for aggravating vascular disease in diabetes. Diabetes Care. 2010 Jul;33(7):1591-7. https://doi.org/10.2337/dc10-0013

28. Filaire E, Alix D, Ferrand C, Verger M. Psychophysiological stress in tennis players during the first single match of a tournament. Psychoneuroendocrinology [Internet]. 2009;34(1):150-7. Available from: https://www.sciencedirect.com/science/article/pii/S030645300800228X https://doi.org/10.1016/j.psyneuen.2008.08.022

29. Arruda AFS, Aoki MS, Paludo AC, Moreira A. Salivary steroid response and competitive anxiety in elite basketball players: Effect of opponent level. Physiol Behav [Internet]. 2017;177:291-6. Available from: https://www.sciencedirect.com/science/article/pii/S003193841631160X https://doi.org/10.1016/j.physbeh.2017.05.017

30. Arruda AFS, Aoki MS, Miloski B, Freitas CG, Moura NR, Moreira A. Playing match venue does not affect resting salivary steroids in elite Futsal players. Physiol Behav [Internet]. 2016;155:77-82. Available from: https://www.sciencedirect.com/science/article/pii/S003193841530202X https://doi.org/10.1016/j.physbeh.2015.12.005 
31. McLellan TM, Caldwell JA, Lieberman HR. A review of caffeine's effects on cognitive, physical and occupational performance. Neurosci Biobehav Rev [Internet]. 2016;71:294-312. Available from: https://www.sciencedirect.com/science/article/pii/S0149763416300690 https://doi.org/10.1016/j.neubiorev.2016.09.001

32. Moreira A, Crewther B, Freitas CG, Arruda AFS, Costa EC, Aoki MS. Session RPE and salivary immuneendocrine responses to simulated and official basketball matches in elite young male athletes. $J$ Sports Med Phys Fitness. 2012 Dec;52(6):682-7.

\section{Tables}

Table 1 Average level of testosterone $(\mathrm{ng} / \mathrm{mL})$ on comparable groups

\begin{tabular}{|c|c|c|c|c|c|c|}
\hline \multirow[t]{2}{*}{ Game } & \multirow[t]{2}{*}{ Code } & \multirow[t]{2}{*}{$\begin{array}{l}\text { Venue } \\
\text { comparison }\end{array}$} & \multirow[t]{2}{*}{$\begin{array}{l}\text { Test } \\
\text { type }\end{array}$} & $\begin{array}{l}\text { Testosterone } \\
(\mathrm{ng} / \mathrm{mL})\end{array}$ & \multirow[t]{2}{*}{$\begin{array}{l}\text { Percentage } \\
\text { Difference }\end{array}$} & \multirow[t]{2}{*}{$\begin{array}{l}P \\
\text { value }\end{array}$} \\
\hline & & & & Mean \pm SEM & & \\
\hline \multirow{12}{*}{$\begin{array}{l}\text { Basketball } \\
n=96\end{array}$} & \multirow{2}{*}{ A } & \multirow[t]{2}{*}{ Home vs Home } & Pre & $5.55 \pm 0.20$ & \multirow[t]{2}{*}{$11 \downarrow \star \star \star$} & \multirow{2}{*}{$\begin{array}{l}< \\
0.0001\end{array}$} \\
\hline & & & Post & $4.94 \pm 0.15$ & & \\
\hline & \multirow[t]{2}{*}{ B } & \multirow[t]{2}{*}{ Away vs Away } & Pre & $5.34 \pm .014$ & \multirow[t]{2}{*}{$16 \downarrow^{\star \star \star}$} & \multirow{2}{*}{$\begin{array}{l}< \\
0.0001\end{array}$} \\
\hline & & & Post & $4.50 \pm 0.11$ & & \\
\hline & \multirow[t]{2}{*}{ C } & \multirow[t]{2}{*}{ Home vs Away } & Pre & $5.55 \pm 0.20$ & \multirow[t]{2}{*}{$4 \downarrow$} & \multirow[t]{2}{*}{0.4} \\
\hline & & & Pre & $5.34 \pm 0.14$ & & \\
\hline & \multirow[t]{2}{*}{ D } & \multirow[t]{2}{*}{ Home vs Away } & Pre & $5.55 \pm 0.20$ & \multirow[t]{2}{*}{$19 \downarrow^{\star \star \star}$} & \multirow{2}{*}{$\begin{array}{l}< \\
0.0001\end{array}$} \\
\hline & & & Post & $4.50 \pm 0.11$ & & \\
\hline & \multirow[t]{2}{*}{ E } & \multirow[t]{2}{*}{ Home vs Away } & Post & $4.94 \pm 0.15$ & \multirow[t]{2}{*}{$8 \uparrow$} & \multirow[t]{2}{*}{0.0667} \\
\hline & & & Pre & $5.34 \pm 0.14$ & & \\
\hline & \multirow[t]{2}{*}{$\mathrm{F}$} & \multirow[t]{2}{*}{ Home vs Away } & Post & $4.94 \pm 0.15$ & \multirow[t]{2}{*}{$9 \downarrow^{*}$} & \multirow[t]{2}{*}{0.0253} \\
\hline & & & Post & $4.50 \pm 0.11$ & & \\
\hline
\end{tabular}

*, ***indicate significance at $P<0.05,0.001$, respectively

Table 2 Average level of cortisol $(\mu \mathrm{g} / \mathrm{dL})$ in comparable groups 


\begin{tabular}{|c|c|c|c|c|c|c|}
\hline \multirow[t]{2}{*}{ Game } & \multirow[t]{2}{*}{ Code } & \multirow[t]{2}{*}{$\begin{array}{l}\text { Venue } \\
\text { comparison }\end{array}$} & \multirow[t]{2}{*}{$\begin{array}{l}\text { Test } \\
\text { type }\end{array}$} & $\begin{array}{l}\text { Cortisol } \\
(\mu \mathrm{g} / \mathrm{dL})\end{array}$ & \multirow[t]{2}{*}{$\begin{array}{l}\text { Percentage } \\
\text { Difference }\end{array}$} & \multirow[t]{2}{*}{$P$-value } \\
\hline & & & & $\begin{array}{l}\text { Mean } \pm \\
\text { SEM }\end{array}$ & & \\
\hline \multirow{12}{*}{$\begin{array}{l}\text { Basketball } \\
n=96\end{array}$} & \multirow[t]{2}{*}{ A } & \multirow[t]{2}{*}{ Home vs Home } & Pre & $9.01 \pm 0.39$ & \multirow[t]{2}{*}{ 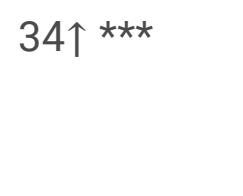 } & \multirow[t]{2}{*}{0.0001} \\
\hline & & & Post & $\begin{array}{l}12.03 \pm \\
0.63\end{array}$ & & \\
\hline & \multirow[t]{2}{*}{ B } & \multirow[t]{2}{*}{ Away vs Away } & Pre & $\begin{array}{l}10.42 \pm \\
0.19\end{array}$ & \multirow[t]{2}{*}{ 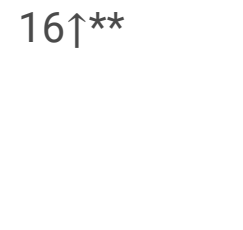 } & \multirow[t]{2}{*}{0.0017} \\
\hline & & & & $\begin{array}{l}12.04 \pm \\
0.45\end{array}$ & & \\
\hline & \multirow[t]{2}{*}{ C } & \multirow[t]{2}{*}{ Home vs Away } & Pre & $9.01 \pm 0.39$ & \multirow[t]{2}{*}{$16 \uparrow * \star$} & \multirow[t]{2}{*}{0.002} \\
\hline & & & Pre & $\begin{array}{l}10.42 \pm \\
0.19\end{array}$ & & \\
\hline & \multirow[t]{2}{*}{ D } & \multirow[t]{2}{*}{ Home vs Away } & Pre & $9.01 \pm 0.39$ & \multirow[t]{2}{*}{ 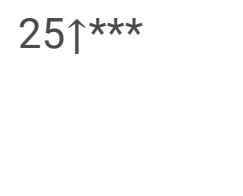 } & \multirow[t]{2}{*}{$<0.0001$} \\
\hline & & & Post & $\begin{array}{l}12.04 \pm \\
0.45\end{array}$ & & \\
\hline & \multirow[t]{2}{*}{$\mathrm{E}$} & \multirow[t]{2}{*}{ Home vs Away } & & $\begin{array}{l}12.03 \pm \\
0.63\end{array}$ & \multirow[t]{2}{*}{$13 \downarrow^{*}$} & \multirow[t]{2}{*}{0.0176} \\
\hline & & & 政 & $\begin{array}{l}10.42 \pm \\
0.19\end{array}$ & & \\
\hline & \multirow[t]{2}{*}{$\mathrm{F}$} & \multirow[t]{2}{*}{ Home vs Away } & Post & $\begin{array}{l}12.03 \pm \\
0.63\end{array}$ & \multirow[t]{2}{*}{-} & \multirow[t]{2}{*}{0.99} \\
\hline & & & 100 & $\begin{array}{l}12.04 \pm \\
0.45\end{array}$ & & \\
\hline
\end{tabular}

$*, * *, * * \star$ indicate significance at $P<0.05,0.01,0.001$, respectively.

Table 3 Psychological state score of basketball players at different venues 


\begin{tabular}{|c|c|c|c|c|}
\hline Psychological Components & Venue & $\mathbf{N}$ & $\begin{array}{l}\text { Score } \\
\text { Mean } \pm \text { SEM }\end{array}$ & $P$-value \\
\hline \multirow[t]{2}{*}{ Cognitive State Anxiety } & Home & \multirow[t]{6}{*}{96} & $2.15 \pm 0.04$ & \multirow[t]{2}{*}{0.584} \\
\hline & Away & & $2.46 \pm 0.04$ & \\
\hline \multirow[t]{2}{*}{ Somatic State Anxiety } & Home & & $2.57 \pm 0.04$ & \multirow[t]{2}{*}{$0.001^{\star}$} \\
\hline & Away & & $2.71 \pm 0.03$ & \\
\hline \multirow[t]{2}{*}{ Self-Confidence } & Home & & $2.14 \pm 0.06$ & \multirow[t]{2}{*}{0.712} \\
\hline & Away & & $2.07 \pm 0.06$ & \\
\hline
\end{tabular}

${ }^{\star} P<0.01$ is considered as significant variation

Table 4 Physical exertion (perception of effort) score of players

\begin{tabular}{|llll|}
\hline Game & Venue & Score & P-value \\
& & Mean \pm SEM & \\
\cline { 1 - 3 } $\begin{array}{l}\text { Basketball } \\
(\mathrm{n}=96)\end{array}$ & Home & $4.17 \pm 0.14$ & $0.000^{*}$ \\
\cline { 2 - 3 } & Away & $5.69 \pm 0.20$ & \\
\cline { 2 - 3 } & & \multicolumn{2}{|c|}{} \\
\hline
\end{tabular}

${ }^{\star} P<0.001$ is considered a significant variation

Figures 


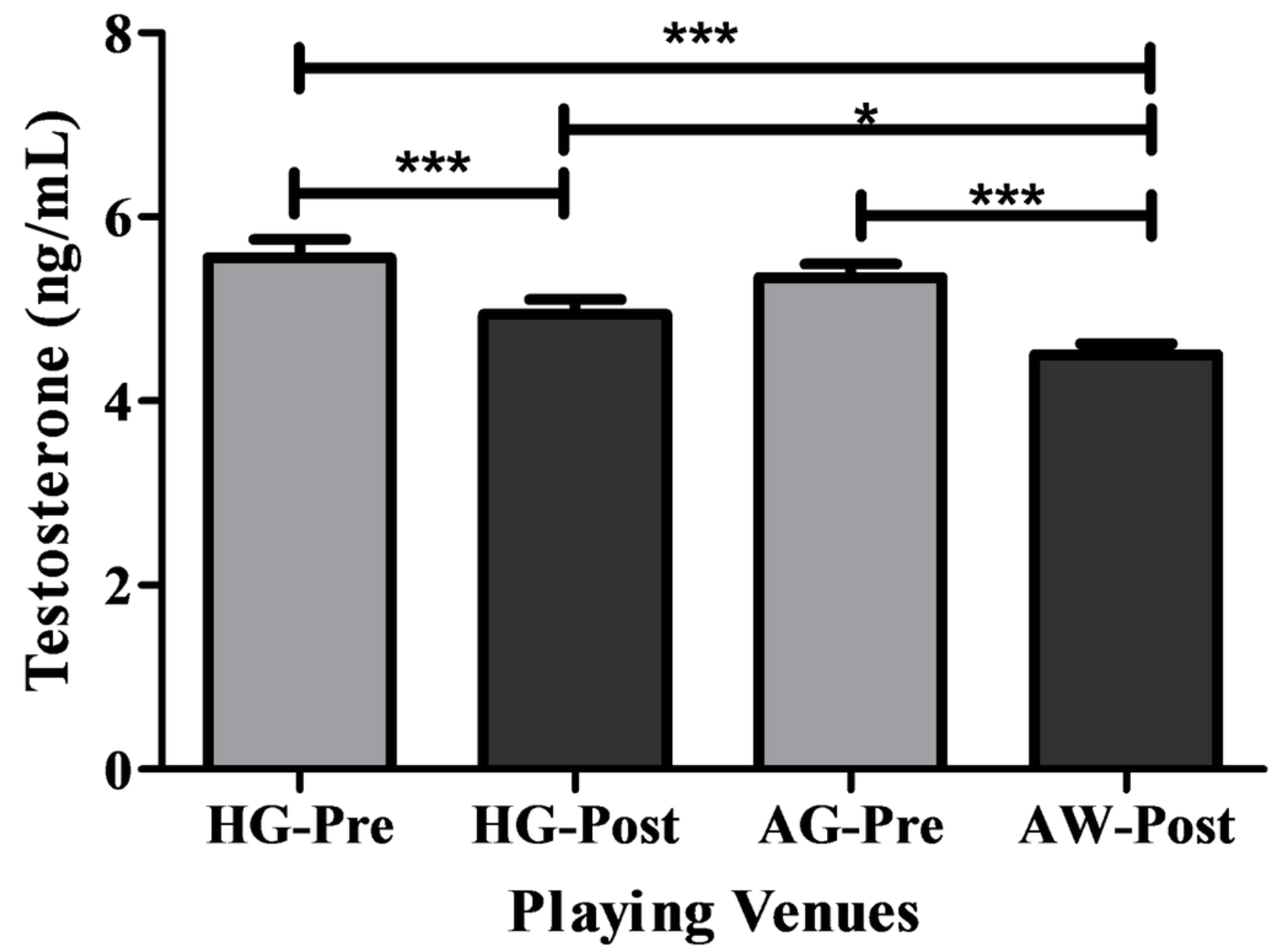

Figure 1

Average level of testosterone $(\mathrm{ng} / \mathrm{mL})$ at different venues 


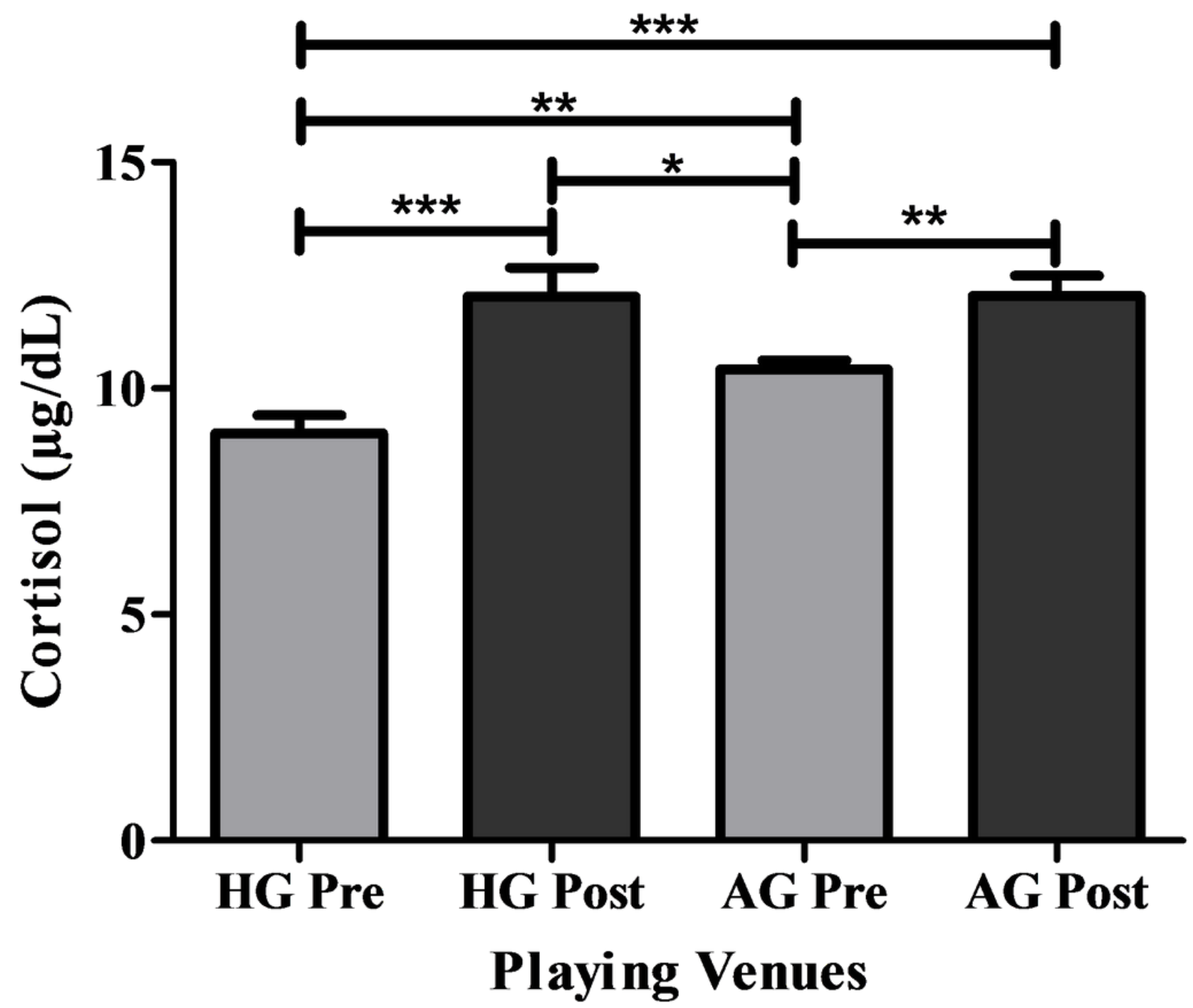

Figure 2

Average level of cortisol $(\mu \mathrm{g} / \mathrm{dL})$ on different venues 


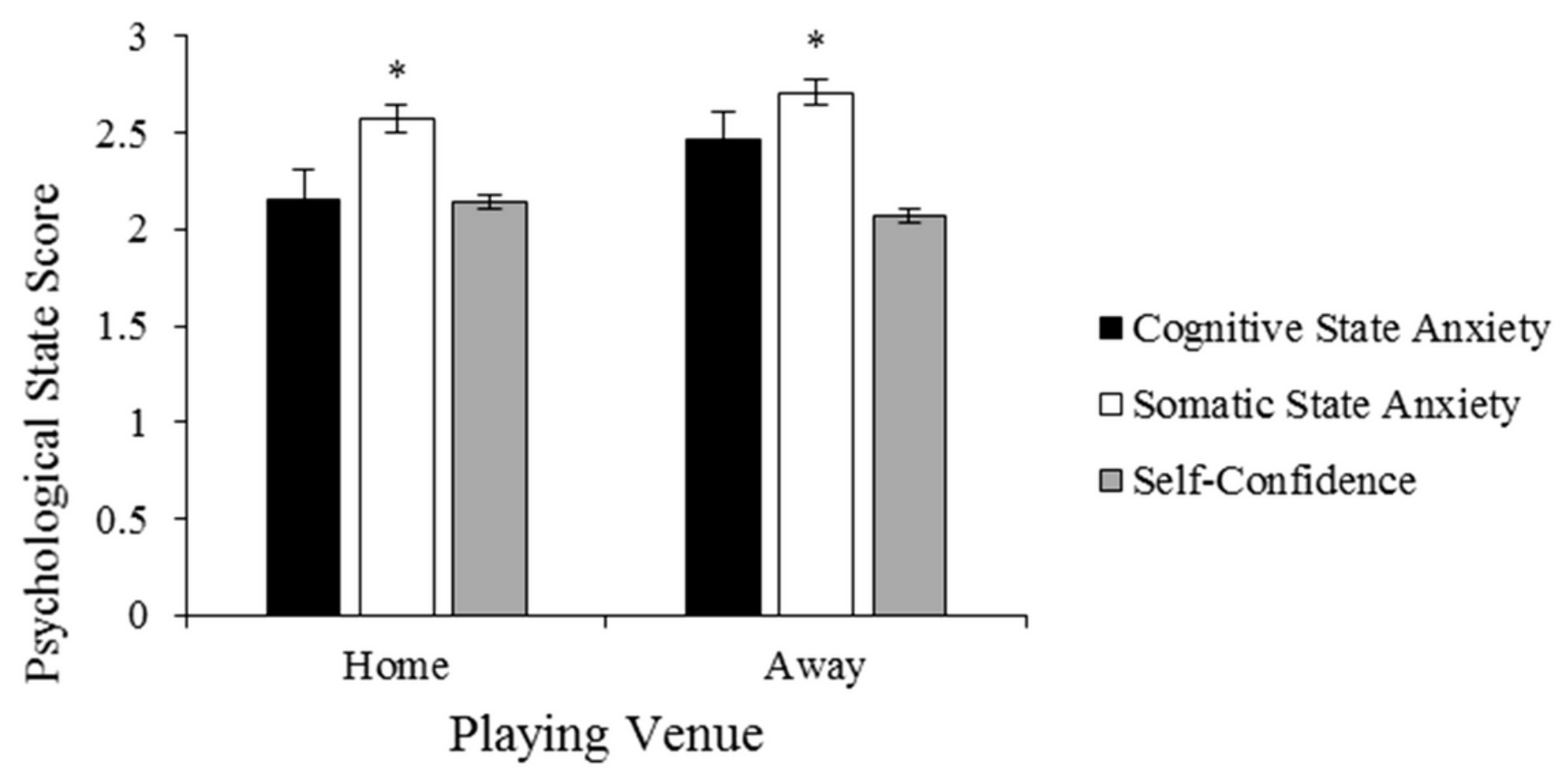

Figure 3

Psychological state score of basketball players

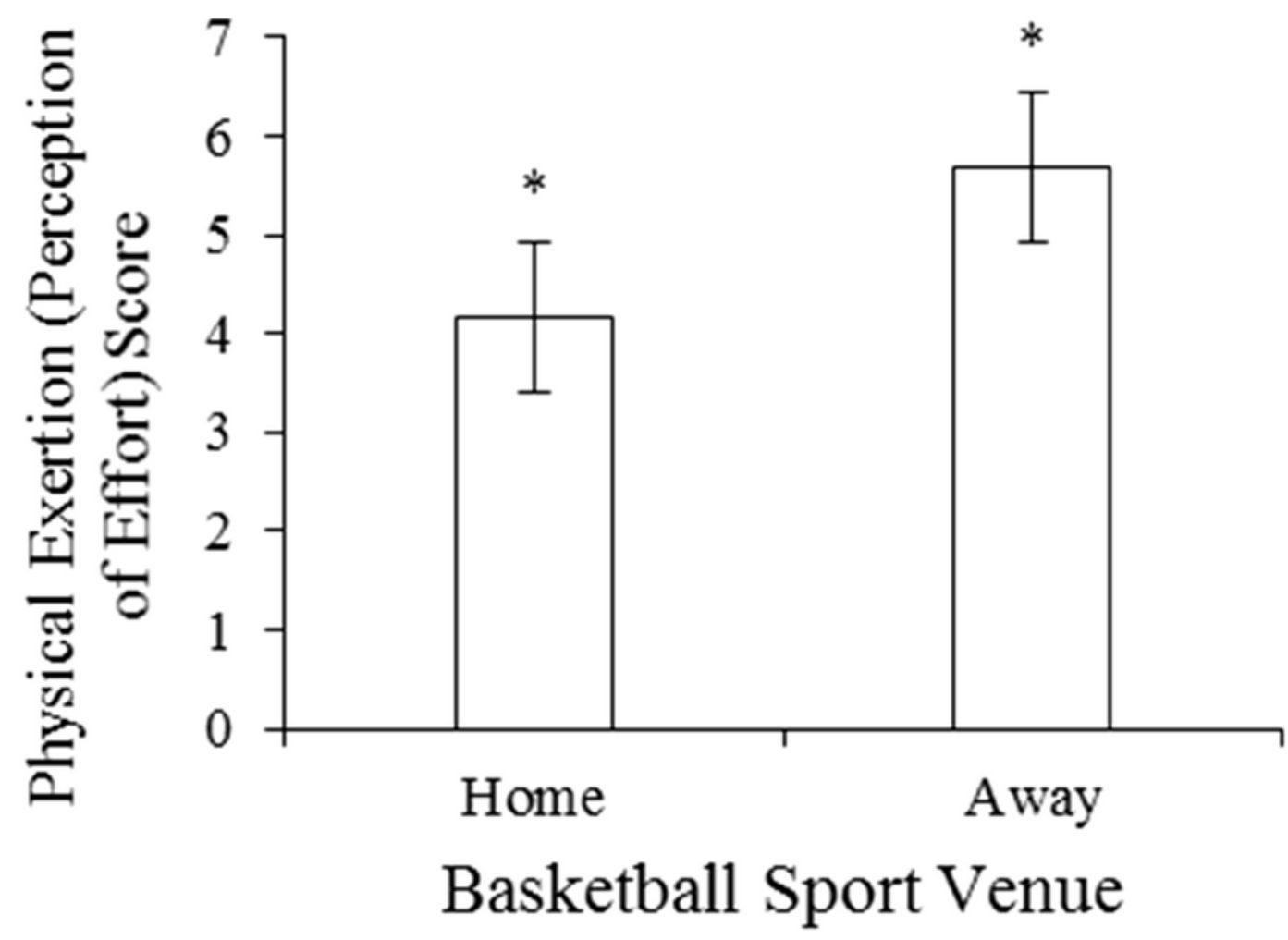

Figure 4 
Basketball players' physical exertion (perception of effort) 